\title{
CERVICAL SMEAR ABNORMALITIES IN HIV INFECTED WOMEN ATTENDING A RURAL HOSPITAL ART CENTER IN TAMILNADU
}

\section{Dr. Jeya Pratheef Muthiah}

\author{
Assistant Surgeon (ART Medical Officer Formerly) Thiruthangal Govt \\ Hospital
}

Dr. Mareeswari. $\mathbf{M}^{*}$ Hospital Tirunelveli. ${ }^{*}$ Corresponding Author

ABSTRACT INTRODUCTION: Cervical cancers are the most common form of cancer encountered in Indian women Studies from India had reported HIV positive women are 10-11 times more prone for cervical carcinomas than HIV negative women with a recent rise in incidence observed. India started a free antiretroviral therapy (ART) program in 2004 with services extended to rural General Hospitals. Cancer cervix can be diagnosed at a preinvasive stage with repeatative papanicolaou smear (cytological screening) and can be readily preventable. AIM: Our aim is to determine the prevalence of PAP smear abnormalities among HIV infected women from rural areas coming for ART initiation and the relationship between immunological status and smear abnormalities. METHODS: As per the Indian National ART program all HIV positive women of reproductive age should undergo PAP smear examination before initiation of ART. All consenting women $>18$ years of age with history of penetrative vaginal intercourse undergo PAP smear examination. In this observational cohort from 25th June 2011 to 15th January 2012 conducted in Melur ART centre and the cytological reports and the patient clinical and immunological status data was analyzed by using SPSS 17 version. RESULTS: 102 PAP smears were obtained and classified according to Bethesda classification. Five patients (4.90\%) were abnormal. Squamous cell carcinoma was observed in 1 (0.98\%) patient with a CD4 count of 580 cells $/ \mathrm{mm} 3$. High squamous intraepithelial lesions were observed in 2 patients ( $1.96 \%)$ with CD4 counts of 208 \& 633 cells/mm3 respectively. Low squamous intraepithelial lesion were observed in 2 patients (1.96\%) with CD4 counts of 50 and 385 respectively cells/mm3. Immunological status (CD4 count) correlated with grade of the initial lesion $(p=0.10)$. All the patients with PAP smear abnormalities were referred to Madurai Medical College Hospital for further treatment and follow-up. CONCLUSION: In our observational study increasing cytological abnormalities in the HIV Infected women were noted. Accordingly, all ART centre and HIV treatment programs should institute comprehensive reproductive health care services for this high-risk groups, including routine Papanicolaou smear screening

\section{KEYWORDS : Antiretroviral Theraphy, HIV, PAP Smear, Cervical Cancer, CD4}

\section{INTRODUCTION:}

Cervical cancers are the most common form of cancer encountered in Indian women. Studies from India had reported HIV positive women are 10-11 times more prone for cervical carcinomas than HIV negative women with a recent rise in incidence observed. India started a free antiretroviral therapy (ART) program in 2004 with services extended to rural General Hospitals. Human papillomavirus (HPV) causes cervical cytological abnormalities such as atypical squamous cells of undetermined significance [ASCUS] and squamous intraepithelial neoplasia [SIL]). Persistent infection with Human papillomavirus is necessary for progression to highgrade SIL and invasive cervical cancer, while both low-risk and high-risk HPV types can cause ASCUS and low-grade squamous intraepithelial neoplasia. Pap smear test is a screening test that can also be a diagnostic test. Cancer cervix can be diagnosed at a preinvasive stage with repeatative papanicolaou smear (cytological screening) and can be readily preventable.

\section{AIM:}

Our aim is to determine the prevalence of PAP smear abnormalities among HIV infected women from rural areas coming for ART initiation and the relationship between immunological status and smear abnormalities.

\section{METHODS:}

As per the Indian National ART program all HIV positive women of reproductive age should undergo PAP smear examination before initiation of ART. All consenting women $>18$ years of age with history of penetrative vaginal intercourse undergo PAP smear examination. This observational cohort study conducted in Melur Antretroviral therapy centre from $25^{\text {th }}$ June 2010 to 15 th January 2012. the cytological reports and the patient clinical and immunological status data was analyzed by using SPSS 17 version.

\section{INCLUSION CRITERIA:}

Patient living with HIV/ AIDS, Age more than 18 yrs with history of vaginal intercourse, Patient who gave consent for testing.

\section{EXCLUSION CRITERIA:}

Patient during Menstural period, vaginal contraceptives, lubricants usage, pregnant patient, unwilling patient

\section{PROCEDURE:}

Take a slide, rotate the spatula with pressure over the entire ectocervix. Spread the cellular material evenly across the glass slide. Immediately spray fix. Allow spray fixative to evaporate. Take a second slide, insert the endocervical brush into the external os and obtain the cell sample. Remove the brush and roll it across the slide to remove the cellular material. Immediately spray fix. Allow spray fixative to evaporate

Epithelial cell abnormalities : Bethesda classification : Squamous cells

- Atypical squamous cells of undetermined significance (ASCUS)

- Low grade squamous intraepithelial lesion (LSIL)

- High grade squamous intraepithelial lesion (HSIL)

- Squamous cell carcinoma

\section{RESULTS:}

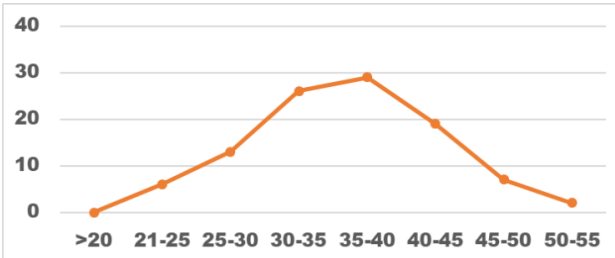

Fig l: Age wise distribution 


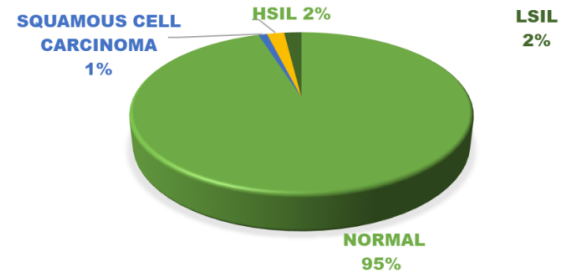

Fig 2: Abnormal PAP smear prevalence

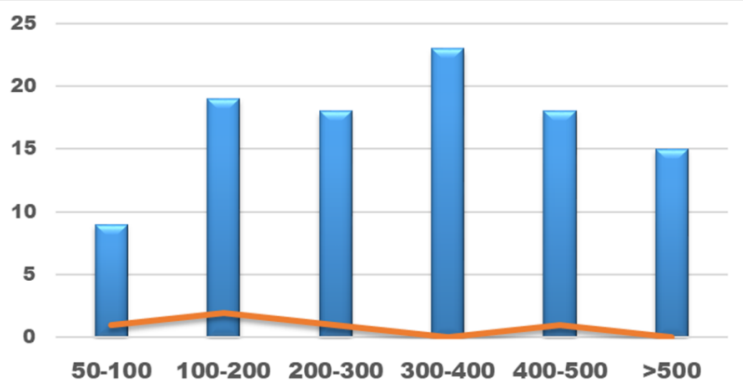

NO OF PATIENTS -ABNORMAL SMEAR

Fig 3: CD4 relation to number of patients and abnormal smear

Table 1: Association between the immunological status and pap smear abnormability

\begin{tabular}{|l|l|l|}
\hline Cd4 count & Smear abnormality & P value \\
\hline$<300$ & 4 & $>0.05$ \\
\hline$>300$ & 1 & \\
\hline
\end{tabular}

\section{Chi-Square Tests}

\begin{tabular}{|c|c|c|c|c|c|}
\hline & Value & df & $\begin{array}{c}\text { Asymp. Sig. } \\
\text { (2-sided) }\end{array}$ & $\begin{array}{c}\text { Exact Sig. } \\
\text { (2-sided) }\end{array}$ & $\begin{array}{c}\text { Exact Sig. } \\
\text { (1-sided) }\end{array}$ \\
\hline $\begin{array}{c}\text { Pearson Chi- } \\
\text { Square }\end{array}$ & 2.000 & 1 & .157 & 1.000 & .500 \\
\hline $\begin{array}{c}\text { Continuity } \\
\text { Correction }\end{array}$ & .000 & 1 & 1.000 & & \\
\hline Likelihood Ratio & 2.773 & 1 & .096 & 1.000 & .500 \\
\hline $\begin{array}{c}\text { Fisher's Exact } \\
\text { Test }\end{array}$ & & & & 1.000 & .500 \\
\hline N of Valid Cases & 2 & & & & \\
\hline
\end{tabular}

\section{DISCUSSION:}

102 PAP smears were obtained and classified according to Bethesda classification. The mean age of participants with SIL was $37 \pm 5$ years. Five patients $(4.90 \%)$ were abnormal. Squamous cell carcinoma was observed in $1(0.98 \%)$ patient with a CD4 count of $80 \mathrm{cells} / \mathrm{mm}^{3}$. High squamous intraepithelial lesions were observed in 2 patients (1.96\%) with CD4 counts of $198 \& 433$ cells $/ \mathrm{mm}^{3}$ respectively. Low squamous intraepithelial lesion were observed in 2 patients (1.96\%) with CD4 counts of 150 and 285 respectively cells $/ \mathrm{mm}^{3}$. In many studies such as Terrumun Z Swende et al. suggested decreased CD4 cell counts and increasing HIV-l RNA viral load were associated with cervical SIL. In our studies Fishers exact test is applied to find the association between immunological status (CD4 count) and smear abnormality. $p$ value was $>0.05$ which concluded that null hypothesis could not be rejected. According to our study there is no strong association between the immunological status and pap smear abnormability.

\section{CONCLUSION:}

In our observational study increasing cytological abnormalities in the HIV Infected women were noted. Accordingly, all ART centre and HIV treatment programs should institute comprehensive reproductive health care services for this high-risk groups, including routine Papanicolaou smear screening. To determine the correlation between immunological status and the SIL , larger number of samples to be taken. Further studies may reveal the effect of antiretro viral therapy (ART) on cervical dysplasia.

\section{REFERENCES:}

1. Ahdieh L, Munoz A, Vlahov D, Trimble CL, Timpson LA, Shah K. Cervical neoplasia and Repeated positivity of human papillomavirus infection in human immunodeficiency virus-seropositive and -seronegative women. Am J Epidemiol. 2000; 151: 1148-1157

2. Davis A, Chakraborty L, Flowers L, Mosunjac M. Cervical dysplasia in women infected with the human immunodeficiency virus (HIV): A correlation with HIV viral load and CD4 + count. Gynecol Oncol 2001; 80:350-354

3. Dorrucci M, Suligoi B, Serraino D, Tirelli U, Rezza G. Italian HIVseroconversion study. Incidence of invasive cervical cancer in a cohort of HIVseropositive women before and after the introduction of highly active antiretroviral therapy. J Acquir Immune Defic Syndr. 2001; 26: 377-380

4. Ellerbrock T, Chiasson M, Bush T, Sun X, Sawo D, Brudney K, Wright T. Incidence of cervical squamous intraepithelial lesions in HIV-infected women. JAMA 2000; 283: 1031-1037

5. Gilles C, Manigart Y, Konopnichki D, Barlow P, Rozenberg S. Management and outcome of cervical intraepithelial neoplasia lesions: a study of matched cases according to HIV status. Gynecologic Oncology 2005; 96: 112-118

6. Harris TG, Burk RD, Palefsky JM, Massad LS, Bang JY, Anastos K, Minkoff $\mathrm{H}$ Hall CB, Bacon MC, Levine AM, Watts DH, Silverberg MJ, Xue X, Melnick SL, Strickler HD. Incidence of cervical squamous intraepithelial lesions associated with HIV serostatus, CD4 cell counts and human papilloma virus test results. JAMA 2005; 293: 1471-1476

7. Heard I, Schmitz V, Costagliola D, Orth G, Kazachkine D. Early regression of cervical lesions in HIV-seropositive women receiving highly active antiretroviral therapy. AIDS 1998; 12: 1459-1464

8. Heard I, Tassie J.-M, Schmitz V, Mandelbrot L, Kazatchkine M, Orth G. Increased risk of cervical disease among human immunodeficiency virusinfected women with severe immunosuppression and high human papillomavirus load. Obstet Gynecol 2000; 96: 403-409

9. Levi JE, Kleter B, Quint W, Fink M, Canto C, Matsubara R, Linhares I, Segurado A,Vanderborght B, Neto J, van Doorn L. High prevalence of human papillomavirus (HPV) infections and high frequency of multiple HPV genotypes in human immunodeficiency virus-infected women in Brazil. J Clin Microbiol. 2002; 40: 3341-3345.

10. Levi JE, Fernandes S, Tateno AF, Motta E, Lima LP Eluf-Neto J, Pannuti CS. Presence of Multiple human papillomavirus types in cervical samples from HIV-infected women. Gynecol Oncol. 2004; 92: 225-31.

11. Glen mola et al. HIV infections in obstetrics and gynaecology PNG Med J 1996:39:190-195 